Nurul Fadilah and Moses Glorino Rumambo Pandin

English Literature Department, Faculty of Humanities ${ }^{1,2}$

Airlangga University

Airlangga Street, No.4 - 6, Gubeng District, Surabaya, East Java 60115

nurul.fadilah-2020@fib.unair.ac.id; moses.glorino@fib.unair.ac.id

\title{
BOOK REVIEW: PANCASILA AND CITIZENSHIP EDUCATION (PENDIDIKAN PANCASILA DAN KEWARGANEGARAAN)
}

Author: Ahmad Sudi Pratikno; City: Jember; Year: 2020; ISBN: 9848925686; 114 pages

As an educational book, the book "Pancasila and Citizenship Education" describes the long journey of Pancasila as the basis of the state, which is the guideline of the Indonesian nation is behaving. So this book was written to foster insight and awareness of the nation and state, attitudes and behaviours of love of the homeland that are codified Pancasila values. It also means that the younger generation is not fooled by the changing era that increasingly deifies technology. Thus, this book aims (in particular) to make the Indonesian nation can filter new changes with Pancasila.

The book "Pancasila and Citizenship Education" can be read in any circles. However, when viewed from the style of language selection (diction), the book is more intended for college students. However, when viewed from the book's contents, the book "Pancasila Education and Citizenship" is also suitable for junior high and high school students because this book explains the history of the establishment of Pancasila and how Pancasila is considered worthy of being the basis of the Indonesian state, where it must be known by all students, especially the next generation of the nation.

In the book "Pancasila and Citizenship Education" discusses the history of the establishment of Pancasila, it also discusses the existence of Indonesia before the existence of Pancasila. That book seems to explain the history of Indonesia through two sides, namely the state of Indonesia before and after Pancasila. It can provide readers with additional information/insights about the country of Indonesia. Because, when the reader reads the title of the book "Pancasila and Citizenship Education", what comes to the reader's mind is the history of Pancasila, not about 
Indonesia. This information can provide added value for the book "Pancasila and Citizenship Education".

A book that deserves to be reviewed so that the Indonesian nation, especially the younger generation, accepts Western culture and outside influences. A book that seems to invite readers to see again how Pancasila was founded and finally legalized as the basis of the state. Until now, Pancasila has been a pillar for Indonesia. That book becomes a new insight for the younger generation that a country will be stronger if its citizens believe and recognize the truth of ideology or state guidelines that have been set by the Government of Indonesia, namely Pancasila. As the ideology of the Indonesian nation, Pancasila is expected to filter and absorb all the bad influences in this era of globalization. Therefore, the review of this book is expected in order that the younger generation can carry out the goals and ideals of the nation.

The book "Pancasila and Citizenship Education" was designed to guide learning about Pancasila Education. The book's content covers the history of the establishment of Pancasila and the values contained in Pancasila for implementation into daily life. As an educational book, it can be used as an introduction for people who want to learn more about Pancasila, a reference lecture that requires detailed information, and the development of the character of the younger generation. In addition, the book is also equipped with the association of Pancasila with the Quran, where the book can also be the foundation in religious research.

The book "Pancasila and Citizenship Education" does not only discuss the history of Pancasila. As I explained above, this reviewed book also discusses the history of Indonesia. How the state of Indonesia before and after Pancasila can awaken the Indonesian nation to 'How important Pancasila as a captain in the state'. The principle of Pancasila has existed since the time of the kingdom in the archipelago. Marking the birth of Pancasila does not necessarily exist because of insistence but rather the result of deliberations that gave birth to big ideas by looking at the state of Indonesia at that time. It ultimately makes Pancasila an appropriate foundation for the state of Indonesia.

The era of globalization makes teenagers easily dethrone the values of Pancasila with existing trends. So prevention is needed through guidelines that can affect the mindset of adolescents. As a guideline, books are a powerful means of influencing one's mindset. It is in line 
with the book "Pancasila and Citizenship Education", which contains the important values of Pancasila which is able to hypnotize the reader to revive the values of Pancasila as a reference in the life of the nation. By re-practising the value of Pancasila that has been lost due to great external influence.

The purpose of the publication of the book "Pancasila and Citizenship Education" is the attitude and behaviour of love of the homeland that is in line with the values of Pancasila. So the effect brought by this book is how to live with Pancasila. Pancasila's lifestyle will influence individuals in thinking and acting by the ideology of Pancasila. Pancasila, which has transformed into a more dynamic millennial approach, is expected to be loved and practised by the younger generation so that the Pancasila lifestyle can touch all levels of Indonesian society.

It can be proven through implementing indicators following the current conditions of the Indonesian nation. The values contained in these indicators teach a way of thinking and acting following the ideology of Pancasila. In other words, when the Indonesian nation implements these values, it will create a prosperous Indonesia.

The evidence is reinforced by the association of Pancasila with ideology and the 1945 Constitution. This connection makes Pancasila very influential for the sustainability of the state. Without Pancasila, Indonesia would be oppressed and die because of the overwhelming external influence. It makes us realize the sacredness of Pancasila in various dimensions. Not only as of the basis of the state, but Pancasila is also an ideology that is upheld for its truth.

On pages 98-99 of the book "Pancasila and Citizenship Education, " Pancasila stated that the nation's view of life is contained in the basic conception of the life you aspire to. The function of Pancasila as a view of life is as an indication of the direction of activities or activities in the life of the nation and state in all fields. All behaviour and actions of Indonesian people must be imbued, and it is the manifestation of the values of Pancasila. In Indonesia, there is no, and there should be no understanding of eliminating or denying the existence of God Almighty (atheism). What should exist is the One Godhead (monotheism) with tolerance for freedom to embrace religion with one's beliefs and to worship according to one's religion. Respectively. Just and civilized humanity is the awareness of human attitudes and actions based on the potential of the human conscience with cultural norms in general; according to just civilized human principles, every 
Indonesian human being is part of a world citizen who believes in the principle of equality and dignity. The principle of unity of Indonesia contains values of harmony and ethical values, which include the value of the position and dignity of Indonesian people to respect the balance between personal and community interests, values that uphold the tradition of struggle and a willingness to sacrifice and defend the honour of the nation and state. In the fourth principle, it is recognized that the Republic of Indonesia adheres to the principles of democracy which are rooted in the values of life which are rooted in the culture of the Indonesian nation; the embodiment of principles of democracy is perceived as an understanding of people's sovereignty, which is rooted in the values of togetherness, kinship, and cooperation. The values contained in the social justice precepts cover the whole of society in all spheres of life, both material and spiritual; this social justice guarantees that every Indonesian citizen is treated fairly in the legal, economic, cultural, and social fields.

The book "Pancasila and Citizenship Education" is written in a formal language or standard language, considering the Pancasila book as an educational book. Although written in formal language, the book also comes with a small glossary at the bottom of the book. Thus it became easier for the reader if they did not understand the term used by the author. Each chapter discussed in the book is described in detail. However, some topics are constantly repeated and sometimes confuse readers because of the differences in the author in describing them. On the other hand, the book's content was written following its purpose-fostering national and state insight and awareness, attitudes, and behaviours of love of the homeland that are a conduit for the values of Pancasila — which continue to be highlighted in each chapter.

The detailed explanation makes the reader seem to have enough with what is presented by the author in the book "Pancasila and Citizenship Education". The word 'enough' describes that the reader already understands the flow of development of Pancasila from tempo to tempo after reading it. The author seems to have been an expert in the discussion of Pancasila and the value wrapped in it. In other words, this is an alternative that readers can choose in resolving the curiosity behind the existence of Pancasila as the basis of the state that glorifies its existence.

The book "Pancasila and Citizenship Education" has advantages that readers can consider in choosing a book. The book's content reviews the history of Pancasila in full and in detail. Students can use it as a reference or course guide and also suitable to increase students' knowledge 
as readers to explore the meaning of Pancasila and its history. The values contained in this book are also very appropriate to be applied in daily life.

In addition to having advantages, this book also has some disadvantages. The book's cover is too simple, which results in the reader not being interested in choosing the book. Then in some chapters, there are paragraphs whose contents are too often repeated. The previous chapter has been explained first, but in the next few chapters, it is explained again. So it tends to get bored when returning to find some parts of the same sentence. In addition, in books often found typos (typing errors) and punctuation errors such as after punctuation periods (.), authors do not start sentences with capital letters.

As a reader, I suggest that each repeated paragraph be replaced with a more detailed explanation of what is being discussed. The reader does not quickly feel bored and interested in the discussion. I also think that this book is suitable for Indonesian children, especially the younger generation who sometimes easily forget the existence of Pancasila. In addition, the values presented in this book are very related to the life of the Indonesian nation, where they can be applied in daily life. Therefore, the book "Pancasila and Citizenship Education" deserves to be on your reading book list.

Nurul Fadilah and Moses Glorino Rumambo Pandin Airlangga University

\section{REFERENCE}

Pratikno, Ahmad Sudi(2020), "Pancasila Education and Citizenship" Al-Falah Assunniyyah Institute of Islam, 1, 1-114.

\section{Author Short-Biodata}

Ahmad Sudi Pratikno is one of the lecturers of Primary School Teacher Education at Trunojoyo Madura University. Ahmad Sudi Pratikno graduated from Jember University and graduated in 
2016. While his master's education, Ahmad Sudi Pratikno was at the Yogyakarta State University and graduated in 2018. In addition to being a writer, Ahmad Sudi Pratikno is a permanent lecturer at Trunojoyo University. 